\title{
PERSISTENT ORGANIC POLLUTANTS IN TWO RESERVOIRS ALONG THE PARAÍBA DO SUL-GUANDU RIVER SYSTEM, RIO DE JANEIRO, BRAZIL
}

Elcia Margareth Souza Brito, Elisa Diniz Reis Vieira, João Paulo Machado Torres* e Olaf Malm

Instituto de Biofísica Carlos Chagas Filho, Centro de Ciências da Saúde, Universidade Federal do Rio Janeiro, Cid. Univ. Ilha do Fundão, 21949-900 Rio de Janeiro - RJ

Recebido em 15/3/04; aceito em 28/3/05; publicado na web em 11/7/05

\begin{abstract}
Sediment contamination is evaluated by determining organic micropollutants (organochlorine compounds - OCs and polycyclic aromatic hydrocarbons - PAHs) in two important Brazilian water reservoirs. Trace levels of OCs were observed in the Santana reservoir (44.8 $\mathrm{ng} \mathrm{g}^{-1}$ d.w. of $p$,p'-DDT), while in the Funil reservoir the levels were below detection level. Forty-eight percent of the found $\Sigma O C$ s were polychlorinated biphenyls, 29\% dichlorodiphenyltrichloroethane (DDT), 18\% Drins, and 5\% other pesticides (HCB, Heptachlor, Heptachlor-epoxide, $\gamma-\mathrm{HCH}$ and a-Endosulfan). We observed lower levels of $\Sigma$ PAH in the Funil reservoir (1 to $275 \mathrm{ng} \mathrm{g}^{-1}$ d.w.) than in the Santana reservoir (2.2 to $26.7 \mu \mathrm{g} \mathrm{g}^{-1}$ d.w.).
\end{abstract}

Keywords: organochlorine compounds; polychlorinated biphenyls; polycyclic aromatic hydrocarbons.

\section{INTRODUCTION}

Persistent organic pollutants (POPs) are substances that even at low concentrations may cause hazard to human health as well as to the environment. Some examples of POPs are the polycyclic aromatic hydrocarbons (PAHs) and the organochlorine compounds (OCs).

The PAHs consist of two or more fused benzene rings in linear, angular or cluster arrangements, containing only carbon and hydrogen ${ }^{1}$. The central molecular structure is held together by stable carbon-carbon bonds. The United States Environmental Protection Agency (EPA) listed 16 PAHs on a list of priority pollutants since they are considered either possible or probable human carcinogens. Hence, their distribution and the possibility of human exposure to them have been the focus of much attention ${ }^{1,2}$. The PAHs have been detected in soil, air, and sediments as well as on various consumable products. They can occur naturally in the environment, mainly as a result of synthesis by plants or after forest and prairie fires ${ }^{3,4}$. However, the greatest amounts of PAHs released into the environment are via anthropogenic processes like fossil fuel combustion and by-products of industrial processing. Agricultural fires as well as cooking may also release $\mathrm{PAHs}^{3,5}$. The distribution of PAHs found in the sediments can give information on precursor sources $^{6,7}$, that is, if they are pyrogenic or petrogenic.

The OCs are organic molecules with linked chlorine atoms, high lipophylicity and, usually, high neurotoxicity. Examples of OCs are the chlorinated insecticides, such as dichlorodiphenyltrichloroethane (DDT) and polychlorinated biphenyls (PCBs).

DDT is a synthetic organochlorine, whose insecticide properties were discovered in 1939, but their use was banned in the 1970's in almost all developed countries due to its toxicity, persistence in the environment, potential bioaccumulation, and insect resistance ${ }^{8}$. It is highly stable under most environmental conditions and very lipophylic $\left(\mathrm{K}_{\mathrm{ow}}: 9.6 \times 10^{5}\right)$, which favors its bioaccumulation throughout the food chain ${ }^{9}$. The DDT may be

*e-mail: jptorres@biof.ufrj.br degraded by UV radiation or by microorganisms, but its main metabolites, dichlorodiphenyldichloroethylene (DDE) and dichlorodiphenyldichloroethane (DDD), are also persistent and toxic $^{10}$. Thus, DDT degradation to DDD or DDE in the environment or in biological tissues can not be considered a detoxification step $^{8}$.

PCBs are chemicals that were widely used in industrial processes from the 1930's until the late 1970's. Although their production ended in the late 1970's, the majority of the cumulative world production of PCBs is still in the environment ${ }^{11}$. PCBs were used extensively in many industrial applications, including in fireresistant transformers and insulating condensers. Prior to 1977, they were used as heat exchanger fluids, and in aluminum, copper, iron and steel manufacturing processing ${ }^{12}$. PCBs were also used as plasticizers, in natural and synthetic rubber products, as adhesives, insulating materials, flame retardant, lubricants in the treatment of wood, clothes, paper and asbestos, chemical stabilizers in paints, pigments and as dispersing agents in formulations of aluminum oxide. PCBs are often found both in the effluent and in the sludge of municipal wastewater. Since PCBs were widely used as dielectric fluids from the 1950's, they are present in transformers in several Brazilian cities, despite its prohibition in the 1980 's ${ }^{13}$. Theoretically, there are 209 different PCB congeners. Many of them are resistant to degradation, which allows them to persist in the environment for a long time and become widespread via atmospheric and water transport mechanisms ${ }^{14}$. Consequently, the PCBs are found in almost every compartment of the global ecosystem including air, water, and soil as well as in animal tissue ${ }^{15}$. Observations in epidemiological and experimental studies have suggested an association between PCB exposure and range of negative health, including neurological, reproductive and immunological alterations in animals ${ }^{11,15,16}$.

In aquatic environments, both PAHs and OCs, due to their physical and chemical characteristics, tend to be retained in bottom sediments. Therefore, sediments may be used as indicators of environmental contamination. The study of sediment cores has shown to be an excellent tool for establishing the effects of anthropogenic and natural processes on depositional environments ${ }^{17,18}$. 
In Brazil, the main industrialized areas are located in the states of São Paulo and Rio de Janeiro. A large percentage of the Brazilian inhabitants population $-21 \%$ live in the São Paulo and Rio de Janeiro metropolitan areas ${ }^{13}$. The Paraíba do Sul River, located between these two Brazilian regions is the main river of Rio de Janeiro State, crossing all its territory. It is also the only source of drinking water for the Rio de Janeiro metropolitan area (with nearly 10 million people). This river receives untreated industrial and domestic wastes from many cities as well as having important highways and railways that cross it.

This work aims to evaluate the sediment contamination by POPs in two important reservoirs of Rio de Janeiro. One is the Santana reservoir, located downstream the main industrial area and other is the Funil reservoir, located upstream this of 'hot spot' (Figure 1). The Funil and Santana reservoirs are interesting areas to study due to their location. The Funil reservoir is near the boundary between São Paulo and Rio de Janeiro States, and indicates the river water quality while it flows into Rio de Janeiro State. The Santana reservoir can indicate the water quality of Paraíba do Sul River that reaches the Guandu River, after passing through many industrial areas. At the end of the Guandu River, at the location of Santa Cruz, the water is driven to the second largest water treatment plant in the world.

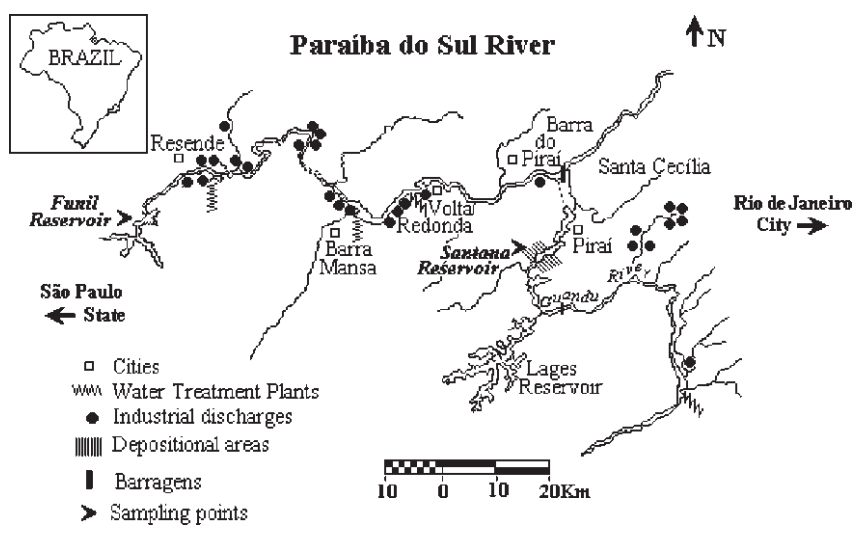

Figure 1. Sampling points: Paraíba do Sul river basin, Brazil

\section{EXPERIMENTAL PART}

\section{Sampling points and procedure}

The sediment samples were collected in 1997 using a PVC tube, with $10 \mathrm{~cm}$ of diameter. The samples taken from the Santana reservoir had $81 \mathrm{~cm}$ of depth and the ones from the Funil reservoir had 30 and $15 \mathrm{~cm}$ of depth. The sample cores were sectioned in $3 \mathrm{~cm}$ thick discs. Each layer was dried at room temperature $\left(20^{\circ} \mathrm{C}\right)$ and stored in acetone rinsed glass jars until analysis.

\section{POP extraction}

We chose a POP extraction methodology that was simple, easy, and didn't use many glass materials. This method required only one Erlenmeyer flask and one shaker, items that are commonly found in labratories. On the other hand, it used large amounts of reagents, compared to other extraction methodologies, such as soxhlet, microwave and/or sonication. All used flasks were precleaned with acetone and heated to $300{ }^{\circ} \mathrm{C}$ during $24 \mathrm{~h}$.

All solvents used were HPLC grade. The POP mixtures and the individual standard components were acquired from Supelco and Aldrich CO. The schematic diagram of POP extraction procedure is presented in Figure 2. The POPs were extracted using $10 \mathrm{~g}$ of sediment and a $100 \mathrm{~mL}$ acetone in an Erlenmeyer flask. After that, $50 \mathrm{~mL}$ of petroleum ether was added, and shaken continuously for $30 \mathrm{~min}$. The suspension was filtered, the acetone was removed with water, and the excess water was removed with $\mathrm{Na}_{2} \mathrm{SO}_{4}{ }^{19}$. The organic solution was submitted to a clean up process, which used $\mathrm{Al}_{2} \mathrm{O}_{3}$ and $\mathrm{Na}_{2} \mathrm{SO}_{3}$ in a chromatographic column eluted with hexane in order to remove humic material and elemental sulfur $^{20}$.

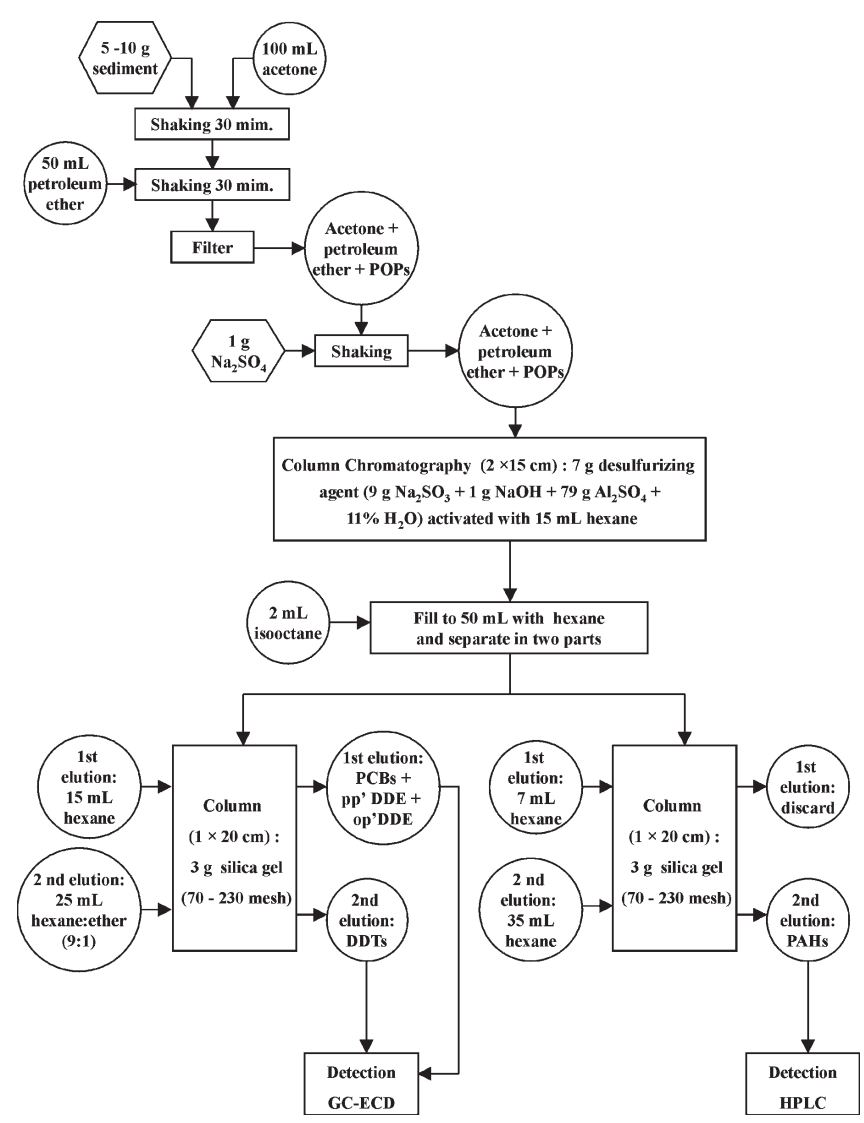

Figure 2. Schematic of POP extraction procedure

The solution was divided in two fractions, one for PAHs and the other for OCs analysis. The PAHs were separated by column chromatography using $3 \mathrm{~g}$ of silica gel 60 (70-230 mesh ASTM) and eluting it with $35 \mathrm{~mL}$ hexane:ethyl ether (3:1). The 16 studied PAHs were: acenaphtene (AE), naphtalene $(\mathrm{N})$, fluorene $(\mathrm{F})$, acenaphthylene (Y), phenanthrene (PA), anthracene (A), fluoranthene $(\mathrm{FL})$, pyrene $(\mathrm{P})$, benz[a]anthracene $(\mathrm{B}[\mathrm{a}] \mathrm{A})$, chrysene $(\mathrm{CH})$, benzo[b]fluoranthene $(\mathrm{B}[\mathrm{b}] \mathrm{F})$, benzo[k]fluoranthene $(\mathrm{B}[\mathrm{k}] \mathrm{F})$, benzo[a]pyrene (B[a]P), indene[1,2,3-cd]pyrene (IP), benzo[g,h,i]perilene $(\mathrm{B}[\mathrm{g}, \mathrm{h}, \mathrm{i}] \mathrm{P})$ and dibenz[a,h]antracene (DB[ah]A). The OCs were also separated by column chromatography using $3 \mathrm{~g}$ of silica gel, which was eluted with 15 $\mathrm{mL}$ hexane, eluting the PCBs $(28,52,101,118,138,153$ and 180), hexachlorobenzene (HCB), heptachlor, heptachlorepoxide, aldrin and $p, p$ '-DDE, and subsequently eluted with $25 \mathrm{~mL}$ hexane:ether (3:1), eluting hexachlorocyclohexane $(\mathrm{HCH}), \alpha$ Endosulfan, dieldrin, endrin and DDT (o,p'-DDE, $p, p^{\prime}$-DDD, $o, p^{\prime}$-DDT and $\left.p, p^{\prime}-\mathrm{DDT}\right)$.

The PAH concentrations were analyzed after an injection of $20 \mu \mathrm{L}$ of the concentrated samples on the HPLC with UV-VIS Detector (Shimadzu LC10-AS pump, ODS-II reverse-phase 
column - 250 X 4,0 mm, Shimadzu SPD-10A UV-Vis detector). An isocratic mixture of acetonitrile/water (80:20) as the mobile phase was used.

The OC analysis was performed by gas chromatography coupled to an electron capture detector (ECD-GC) (Shimadzu GC-14B with autosampler AOC-17) with capillary columns (Shimadzu CBP1 and CBP5). The carrier gas was hydrogen. The injector and detector temperatures were 300 and $310^{\circ} \mathrm{C}$, respectively. The oven temperature program starts at 110 (for $1 \mathrm{~min}$ ), rising to 170 (at $20{ }^{\circ} \mathrm{C}$ per min) and subsequently to $290{ }^{\circ} \mathrm{C}$ (at $7.5^{\circ} \mathrm{C}$ per min), where it remained for $12 \mathrm{~min}$.

\section{Analytical quality control}

The detection limits (DL) were calculated as being three times the standard deviation of the blank concentrations, and they are in the range of 17.0 to $54.0 \mathrm{ng} \mathrm{L}^{-1}$ for individual PAHs and 0.2 to $1.5 \mathrm{ng} \mathrm{L}^{-1}$ for the OCs.

Evaluation recovery was done only for PAHs, using 5 and $10 \mathrm{~g}$ of a reference sediment sample, "Riza B", provided by the Institute for Environmental Studies (RIZA, Netherlands). The extraction with $5 \mathrm{~g}$ of sediments had lower extraction efficiency. Some compounds, such as B[b]F, B[a]P, DB[a,h]A, IP and B[g,h,i]P, showed concentrations below the detection limit. The recovery range (except those below DL) was from 25.7 to $44.4 \%$. When $10 \mathrm{~g}$ of sediment were employed, all 16 PAHs were extracted. The extraction's efficiency ranged from $27.9 \pm 1.8$ to $89.8 \pm 33.9 \%$ (average, $43 \pm$ $17 \%$ ). These results were similar to the efficiency found in other experiments using soxhlet extraction ${ }^{21}$.

\section{RESULTS AND DISCUSSION}

\section{Organochlorine compounds}

Organochlorine compounds were not observed in the Funil Reservoir (below detection limit concentration), while in Santana we observed trace levels of OC compounds (Figure 3). The highest values were observed for $\Sigma$ DDT at $48 \mathrm{~cm}$ depth (44.8 $\mathrm{ng} \mathrm{g}^{-1} \mathrm{~d}$.w.)

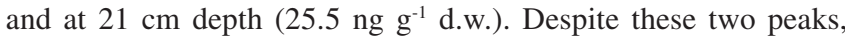
$48 \%$ of the OCs found in the Santana Reservoir were PCBs, $29 \%$ DDT, 18\% Drins (aldrin, dieldrin and endrin) and 5\% other pesticides (HCB, Heptachlor, Heptachlorepoxide, $\gamma$-HGH and $\alpha$ Endosulfan). We supose that the introduction of chemically persistent organochlorine pesticides depends mainly on the intensity and the kind of agricultural activities. The Paraíba do Sul basin drains a great area that is influenced by industrial and agricultural activities, besides having an intense highway traffic and urbanization along of the river borders.

Small amounts of PCBs were found (Table 1), from $<$ DL to $19,3 \mathrm{ng} \mathrm{g}^{-1}$ d.w. at $60 \mathrm{~cm}$ of depth. The PCBs represented $48 \%$ of OC contamination for the Santana reservoir similar to what was observed by Torres ${ }^{13}$ in sediment samples of the main Tapajós River basin (3 - 61 ng. g $^{-1}$ d.w.). The values observed suggest the increased use of PCBs in the recent past, probably corresponding to the period of peak production and/or use. There are still a countless number of electric transformers and capacitors around the cities filled with ASKAREL, a mineral oil containing PCBs. At least one accident was reported in which around $200 \mathrm{~kg}$ of this oil were released upstream the Santana reservoir ${ }^{22}$.

The DDT percentage and its metabolites, DDE and DDD, were 56, 27 and 18\% respectively (Table 1 and Figure 3). The First restrictions to DDT use in Brazil were introduced in late 1970's. The prohibition of organochlorine pesticides in the entire country

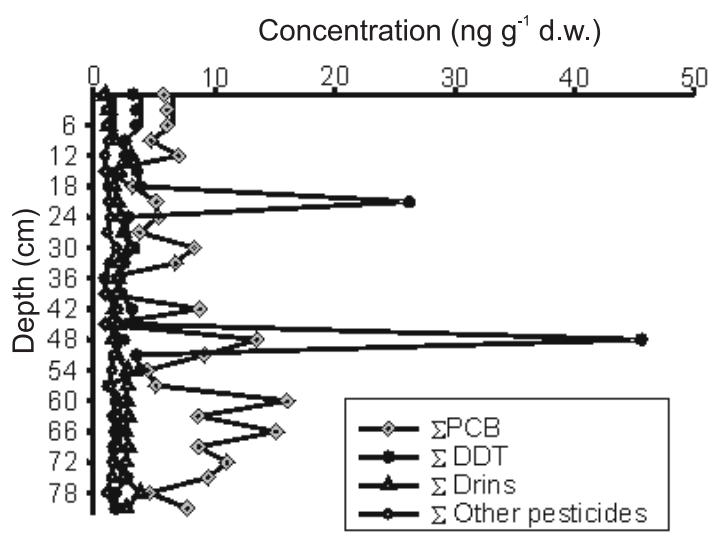

Figure 3. Distribution of $O C s$ (DDT, $P C B$, Drins and other organochlorine pesticides) in a sample core of the Santana Reservoir.

came in 1985. Although, at the end of 1984, a national campaign for malaria eradication was still taking place. Lindane was one of the primary OC insecticides used during this period ${ }^{23}$. In 1988, only two years after the use of DDT had been prohibited, Souza et $a l .{ }^{24}$ studied the organochlorine contamination in agricultural soils in southern Brazil, and found $268 \mathrm{mg} \mathrm{kg}^{-1}$ of DDT in the soil of soy and wheat crops. In the same year, Japenga et al. ${ }^{25}$ observed 10-81 $\mathrm{ng} \mathrm{g}^{-1}$ of DDT metabolites in sediments collected at Rio de Janeiro coastal bays and lagoons. More recently, Tavares et al. ${ }^{23}$ identified in the sediment samples collected in the summer of 1994/1995 from Baía de Todos os Santos (BA), 22-34 ng g-1 of DDT. Although the use of DDT for agricultural purposes is prohibited in Brazil for a long time, the chemical is still available for malaria control and other diseases transmitted by insects and therefore continues to be introduced into the environment ${ }^{8}$. A public health DDT spraying program was conducted in 1990 in the neighborhood of Jacarepagua, near the city of Rio de Janeiro, to control American cutaneous leishimaniasis, the sixth leading infectious parasitic disease in the world ${ }^{8}$. Since 1993, the Brazilian government recommends the replacement of DDT with pyrethroids. Besides this, the illegal use of DDT in agriculture after the prohibition, although not proven, may also have introduced DDT derivatives into the environment.

On the other hand, comparing the DDT data of Souza et al. ${ }^{24}$, or even of Tavares et al. ${ }^{23}$, with ours (Table 1) we find that DDT contamination is diminishing. The persistence of DDT permits interactions between the pesticides and the soil ${ }^{26}$, and the higher DDT lipophilicity favors its absorption by the soil particles rich in organic matter. In general, a half-life of up to near 7 years has been suggested for DDT in temperate regions ${ }^{9,27}$, while in tropical countries, they are estimated to be around 1-5 years ${ }^{28}$. These estimates, obtained in laboratory controlled conditions, might not reflect real environmental conditions, mainly the ones for tropical countries where the environmental factors that may be influencing DDT geo-chemical degradation are not completely known. The levels of DDT observed in this study could eventually be explained as a result of the continuous run off to the Paraíba do Sul River. The relatively high concentration of non-metabolized DDT might be due to recent DDT inputs in the area and to its low degradability by chemical, physical and biological activities. Therefore, our results indicate that recent DDT inputs may have occurred, although we can not specify their exact origin. Despite this lack of data, these results serve to warn the government that there is still much to do in controlling the illegal commercialization of prohibited chemicals. 
Table 1. POP concentration (ng g $\mathrm{g}^{-1}$ d.w.) of sediment samples from Brazil, mean \pm SD (min.- $\max$.)

\begin{tabular}{lcccc}
\hline Reservoir & PAHs & PCBs & DDT & Drins. \\
\hline Santana & $8,754 \pm 6,168$ & $5.27 \pm 4.3$ & $3.31 \pm 6.9$ & $1.29 \pm 0.6$ \\
Funil & $(2,221-26,720)$ & $(1.71-19.3)$ & $(<\mathrm{DL}-34.2)$ & $(<\mathrm{DL}-2.94)$ \\
& $72(2-275)$ & $1.5 \pm 0.9(<\mathrm{DL}-2.9)$ & $1.7 \pm 2.3(<\mathrm{DL}-6.1)$ & $<$ DL \\
\hline
\end{tabular}

* Detection limit: HPAs: $17-54 \mathrm{ng} \mathrm{L^{-1 }}$ and OCs $0.2-1.5 \mathrm{ng} \mathrm{L^{-1 }}$

\section{Polycyclic aromatic hydrocarbons}

At two sampling points of the Funil Reservoir, low levels of $\Sigma$ PAH were observed. The total concentrations of 16 priority PAHs varied from $<\mathrm{DL}$ to $275 \mathrm{ng} \mathrm{g}^{-1} \mathrm{~d}$.w. (Table 1). The major contribution (96 to 100\%) is constituted by PAHs with less than 3 rings, except for the sampling point 2 at the surface and at $15 \mathrm{~cm}$ of depth, where levels a little bit higher of $\mathrm{P}$ and FL concentration were observed (20 $\mathrm{ng} \mathrm{g}^{-1}$ d.w.).

It deserves to be noted that at the Santana reservoir higher levels of micropollutants were observed (Table 1). The highest concentrations were observed at a depth of 69-81 cm (Table 2). The $\Sigma$ PAHs concentrations varied from $2,2 \mu \mathrm{g} \mathrm{g}^{-1} \mathrm{~d}$.w. at $45 \mathrm{~cm}$ of depth to $26,7 \mu \mathrm{g} \mathrm{g}^{-1}$ d.w. at $72 \mathrm{~cm}$ of depth, and the major part of these was composed by PAHs with 4 rings (Table 2). Our results were similar to the ones observed by Torres et al.$^{20}$ for river sediment samples. Figure 4 shows the distribution of PAHs groupings. Naphthalene (only 2 rings) showed the lowest levels, like the sum of 2 and 3-rings PAHs (AE, N, F, AY, PA and A). This distribution pattern may be due more to the higher biodegradability of these compounds than the PAHs with more than 3-rings (PAHs with less than three rings can be lost during analysis due to their higher volatility,). Larger PAHs showed the highest concentrations, mainly below of $54 \mathrm{~cm}$ depth.

On the Santana reservoir core the A and $\mathrm{B}[\mathrm{a}] \mathrm{P}$ concentrations were in mean 280 and $635 \mathrm{ng} \mathrm{g}^{-1}$ respectively. These PAH isomers are indicative of the local source due to the fact that they are very photoreactive, and can not be transported by the atmosphere for long distances. The principle PAH isomers observed in the Santana reservoir core were FL and P (at about 1500 and $1200 \mathrm{ng} \mathrm{g}^{-1}$ respectively), which are very stable $\mathrm{PAH}$, but reasonable contributions were also observed with F, PA, DB[ah]A, IP, and $\mathrm{B}$ [ghi]P (an average 350 and $500 \mathrm{ng} \mathrm{g}^{-1}$ ).

Parent PAH combustion and/or anthropogenic input is often inferred from an increase in the proportion of less to more stable isomers ${ }^{29}$. The relative stability of parent PAHs was calculated from the relative heat of formation ${ }^{30}$. They suggested that isomers of masses 276 (e.g. B[g,h,i]P and IP) and 202 (e.g. P and FL) have the greatest range of stability and hence are good indicators of thermodynamic vs. kinetic (e.g. petroleum vs. combustion) sources.

Table 2. Concentrations (ng $\mathrm{g}^{-1}$ d.w.) of PAHs in a core sample of Santana Reservoir

\begin{tabular}{|c|c|c|c|c|c|c|c|c|c|c|c|c|c|c|c|c|c|}
\hline $\begin{array}{l}\text { Depth } \\
(\mathrm{cm})\end{array}$ & $\mathrm{AE}$ & $\mathrm{N}$ & $\mathrm{F}$ & AY & $\mathrm{PA}$ & A & FL & $\mathrm{P}$ & $\begin{array}{c}\text { Chry+ } \\
\text { BaA }\end{array}$ & $\mathrm{BbF}$ & $\mathrm{BkF}$ & $\mathrm{BaP}$ & DbahA & IP & BghiP & $\begin{array}{c}\text { PAH } \% \\
\text { total }\end{array}$ & $\mathrm{OM}$ \\
\hline 0 & 51 & $<\mathrm{LD}$ & 294 & 282 & 283 & 75 & 891 & 792 & 1127 & 515 & 401 & 376 & 356 & 59 & 85 & 5586 & 12 \\
\hline 3 & 59 & $<\mathrm{LD}$ & 307 & & 327 & 90 & 1019 & 903 & 1113 & 528 & 217 & 396 & 85 & 134 & 175 & 5354 & 13 \\
\hline 6 & 51 & $<\mathrm{LD}$ & 279 & & 279 & 71 & 883 & 785 & 1006 & 433 & 428 & 386 & 40 & 139 & 175 & 4955 & 13 \\
\hline 9 & 72 & 12 & 432 & & 378 & 97 & 1201 & 1074 & 1437 & 679 & 666 & 606 & 114 & 109 & 196 & 7072 & 15 \\
\hline 12 & 29 & 8 & 214 & & 224 & 74 & 827 & 687 & 932 & 695 & 572 & 505 & 245 & 390 & 411 & 5813 & 12 \\
\hline 15 & 22 & 9 & 201 & & 226 & 48 & 840 & 685 & 994 & 710 & 593 & 505 & 264 & 373 & 398 & 5869 & 14 \\
\hline 18 & 35 & 8 & 228 & & 218 & 73 & 781 & 652 & 923 & 658 & 560 & 500 & 229 & 374 & 393 & 5632 & 14 \\
\hline 21 & 23 & 11 & 171 & & 158 & 53 & 540 & 462 & 627 & 489 & 420 & 365 & 213 & 278 & 301 & 4109 & 9 \\
\hline 24 & 29 & 9 & 196 & & 204 & 68 & 735 & 619 & 1449 & 626 & 531 & 472 & 225 & 344 & 349 & 5857 & 13 \\
\hline 27 & 33 & 10 & 228 & & 232 & 63 & 774 & 678 & 865 & 632 & 545 & 423 & 255 & 334 & 286 & 5358 & 13 \\
\hline 30 & 32 & 8 & 214 & & 258 & 91 & 938 & 769 & 1124 & 773 & 650 & 557 & 303 & 456 & 438 & 6611 & 14 \\
\hline 33 & 78 & 16 & 540 & & 610 & 243 & 2023 & 1710 & 336 & 197 & 132 & 39 & 177 & 7 & 32 & 6140 & 26 \\
\hline 36 & 54 & 528 & 560 & & 152 & 1672 & 1710 & 1362 & 311 & 105 & 42 & 120 & 176 & 6 & 38 & 6838 & 32 \\
\hline 39 & 39 & 528 & 560 & & 152 & 1672 & 1473 & 803 & 296 & 105 & 31 & 120 & 176 & 6 & 38 & 5999 & 30 \\
\hline 42 & 46 & $<\mathrm{LD}$ & 322 & & 380 & 143 & 962 & 865 & 174 & 97 & 65 & $<\mathrm{LD}$ & 88 & $<\mathrm{LD}$ & $<\mathrm{LD}$ & 3141 & 42 \\
\hline 45 & 27 & 217 & 319 & & 230 & 86 & 600 & 552 & 90 & 38 & 28 & $<\mathrm{LD}$ & 35 & $<\mathrm{LD}$ & $<\mathrm{LD}$ & 2221 & 12 \\
\hline 48 & 65 & 2 & 359 & & 418 & 156 & 1171 & 999 & 175 & 94 & 76 & $<\mathrm{LD}$ & 120 & $<\mathrm{LD}$ & $<\mathrm{LD}$ & 3636 & 13 \\
\hline 51 & 85 & 4 & 531 & & 527 & 192 & 1281 & 1133 & 188 & 82 & 66 & $<\mathrm{LD}$ & 89 & $<\mathrm{LD}$ & $<\mathrm{LD}$ & 4178 & 14 \\
\hline 54 & 34 & 2 & 288 & & 333 & 77 & 1058 & 881 & 1301 & 849 & 648 & 654 & 402 & 430 & 480 & 7437 & 14 \\
\hline 57 & 29 & 16 & 328 & & 376 & 108 & 1319 & 1005 & 1446 & 964 & 751 & 774 & 404 & 405 & 488 & 8413 & 13 \\
\hline 60 & 123 & 581 & 700 & & $<\mathrm{LD}$ & 154 & 2324 & 1807 & 2502 & 1666 & 1315 & 1261 & 734 & 648 & 811 & 14625 & 9 \\
\hline 63 & 50 & $<\mathrm{LD}$ & 573 & & 717 & 169 & 2245 & 1878 & 2800 & 1943 & 1509 & 1435 & 861 & 837 & 1009 & 16026 & 16 \\
\hline 66 & 35 & 2 & 283 & & 366 & 95 & 1156 & 997 & 1588 & 1079 & 896 & 861 & 520 & 515 & 586 & 8978 & 22 \\
\hline 69 & 44 & 3 & 365 & & 464 & 110 & 1597 & 1391 & 2088 & 1491 & 1181 & 1177 & 790 & 812 & 897 & 12410 & 14 \\
\hline 72 & 90 & $<\mathrm{LD}$ & 937 & & 1240 & 297 & 4157 & 3453 & 4328 & 3424 & 2690 & 2690 & 930 & 992 & 1492 & 26720 & 14 \\
\hline 75 & 69 & 4 & 867 & & 989 & 626 & 2819 & 2417 & 3494 & 2310 & 1422 & 1287 & 911 & 1064 & 1335 & 19612 & 14 \\
\hline 78 & 78 & 16 & 3054 & & 1312 & 867 & 3610 & 3044 & 3632 & 2299 & 1444 & 1317 & 665 & 893 & 1133 & 23363 & 10 \\
\hline 81 & 4 & $<\mathrm{LD}$ & 580 & & 684 & 503 & 1880 & 1401 & 2511 & 1502 & 893 & 945 & 703 & 734 & 830 & 13169 & 9 \\
\hline
\end{tabular}


On the other hand, masses 278 (e.g. DB[ah]A) and 228 (e.g. $\mathrm{CH}$ and $\mathrm{B}[\mathrm{a}] \mathrm{A})$ show little promise as such indicators.

PAHs of molecular masses 178 and 202 are commonly used to distinguish between combustion and petroleum sources ${ }^{6,31,32}$. The higher mass PAHs are usually minor contributors to refined petroleum products ${ }^{33}$ and are generally present in significant amounts only in fractions like asphalt and possibly in bitumen or coal $^{34}$. Otherwise, the higher mass PAHs are appreciate constituents in samples of wood $\operatorname{soot}^{35}$, but only marginally detectable in wood smoke and aerosol ${ }^{36,37}$.

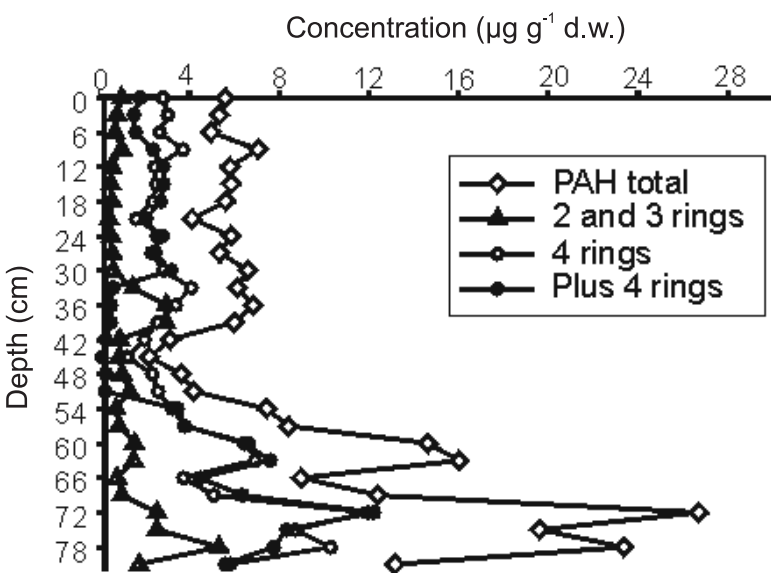

Figure 4. The distribution of PAHs in a core sample of the Santana Reservoir.

Volatile pollutants can be easily transported over long distances when favored by meteorological conditions. PAHs have been detected even in the most remote areas of the globe due to longrange transport ${ }^{38}$. PAHs with two or three rings are widely dispersed by winds, while larger ones are deposited near to source point. Fine particles originating from combustion or central heating are transported by the wind and, with precipitation, are carried out and deposited on the upper surface. When deposited, by runoff or atmospheric deposition, these particles may be trapped in the rivers and lakes. The behavior of the deposition of particles above the soil and above the sediments is slightly different. The particles that lie over the soil are subjected 'only' to aerial dispersion, while the particles that lie over the water are also subjected to hydrodynamic dispersion ${ }^{39}$. Once the particle enters the water, it will not be dissolved because of its lipophilicity, but it will be adsorbed to smaller particles and deposited on the surface sediment $(<20 \mu \mathrm{m})^{40}$. The amount of protection is also dependent on encapsulation of PAHs with a particle, instead of adsorption on the surface, and of particle color that can protect from photodegradation ${ }^{41}$. The pyrogenic PAH is generally associated with soot-rich particles that protect them from degradation in the atmosphere, water and sediments ${ }^{41,42}$. Given the larger particle size of wood soot, PAHs from forest fires will not travel far, and they will be better protected against photolitic degradation. Therefore, the wood combustion PAH signature can be expected to survive the transfer from the atmosphere to soil and into sediments.

The origin of the PAHs may be inferred by three indirect methods: correlation with $\mathrm{Pb}$ concentration, correlation with organic carbon and from ratios between PAH isomers (indices). The correlation with $\mathrm{Pb}$ concentration is normally used in the countries where this metal is added to gasoline, which is not the case in Brazil. The correlation between PAH concentrations and the organic carbon content, can be used for a possible indicator of aerial transportation ${ }^{43}$. The relationship between total PAH concentration and organic matter was investigated in this work by linear regression analysis and no significant relationship was obtained.

The merit of using some PAHs as "marker" compounds, for given emission sources, depends on the type of the deposited particle.

Changes in PAH patterns may reflect changes in the sources of PAHs such as coal, oil, gas and petroleum combustion ${ }^{44}$. The ratios of PAH components may be used as indicators for inferring PAH sources. There exists a vast literature about the kinds of molecular indices $^{43,45,46}$. The use of PAH ratios for source assignments in sediments requires the understanding of the relative thermodynamic stability of different PAHs, the characteristics of different PAH sources and the changes in PAH composition between source and sediments ${ }^{46}$. Table 3 shows some molecular indices commonly used. These were applied to the Santana reservoir core data. Almost all used PAH ratios suggested the pyrogenic source, except the IP/ $(\mathrm{IP}+\mathrm{B}[\mathrm{ghi}] \mathrm{P})$ ratio that suggested a little contribution from vehicle emissions (0.4 at a depth $0-9 \mathrm{~cm}$ and $72-78 \mathrm{~cm}$ ) and also from petrogenic source $(<0.2$ between $33-51 \mathrm{~cm}$ depth). The presence of vehicular emission markers is probably influenced by the proximity to the Presidente Dutra highway. This highway crosses the Paraíba do Sul River in some points, while in others it follows aside, before the Santana reservoir. The IP/IP+B [ghi]P index is interesting because it can indicate more specifically the $\mathrm{PAH}$ origin: ratios of $\mathrm{IP} / \mathrm{IP}+\mathrm{B}$ [ghi] $\mathrm{P}$ less than 0.2 suggest petroleum sources; ratios between 0.24 and 0.40 indicate vehicle emissions (e.g. combustion products of gasoline, kerosene, diesel and crude oil); ratios above 0.50 are typical of grass combustion, wood soot, creosote, almost all bush fires as well as wood and coal combustion aerosols. The observed variation in petroleum composition of our data is probably a combination of heterogeneous samples ${ }^{47}$.

Table 3. Literature PAH ratios for sources indicative

\begin{tabular}{lccc}
\hline Ratio (Ref.) & \multicolumn{2}{c}{$\begin{array}{c}\text { Indicative of source } \\
\text { Petrogenic }\end{array}$} & $\begin{array}{c}\text { Pyis workenic } \\
\text { (Santana reservoir) }\end{array}$ \\
\hline PA/A $^{(31)}$ & $>25$ & $<10$ & 1.4 \\
FL/P $^{(29)}$ & $<1$ & $>1$ & 1.2 \\
IP/B[g,h,i]P(17) $^{(10)}$ & $>1$ & $<1$ & 0.8 \\
A/PA $^{(30)}$ & $<0.1$ & $>0.1$ & 0.7 \\
FL/(FL+PA) $^{(30)}$ & $<0.1$ & $>0.1$ & 0.8 \\
FL/(FL+P) $^{(30)}$ & $<0.5$ & $>0.5$ & 0.6 \\
IP/(IP+B [ghi]P) $^{(30)}$ & $<0.2$ & $>0.5$ & 0.5 \\
\hline
\end{tabular}

On the other hand it is reasonable to suppose that most of PAH contribution to Santana reservoir is from pyrogenic source, since fires are usually observed all over the region, especially between August and September. These fires occur for two reasons: first the winter season in the region is dry and relatively hot. Add to this the fact that the forest cover of the valley has been almost completely replaced by grass and sparse bushes - natural and human induced fires are easily started. Second, the valley is also an agricultural area and, in Brazil, the farmers still have the habit of burning the agricultural areas before preparing the soil to be cultivated. This result also agrees with the composition of PAH isomers because the larger HPAs tend to be more prevalent in emission from grass fires than wood fires ${ }^{36,48}$.

Studies for environmental characterization, such as estimates of sediment rates, are still lacking for tropical countries. The dating of sediment cores using radioactive tracers, like ${ }^{210} \mathrm{~Pb}$, permits the precise quantification of the history of input in a system ${ }^{49}$. Still, it is not always possible to estimate the sedimentation rates due to 
practical problems, for example, analysis cost. Sometimes, in the absence of reliable dating, it is possible to estimate sedimentation rates by the concentration profile of a pollutant. Then, an increase of concentration in the surface layers can be attributed to the installation of a known polluting source and, below these enriched layers, background concentrations should be measured ${ }^{17,50}$. However, it is not the case of the reservoirs studied here and, unfortunately, sediment core dating was not done. Even though we can not guarantee the bioturbation absence on surface layer and we don't have the sedimentation rates, the chemical analytical quality qualify the environmental, as well as public health, importance of this work.

\section{CONCLUSIONS}

The Funil reservoir was not contaminated by POPs whereas at the Santana reservoir we found a moderate to low contamination. The pattern observed for the two core samples suggest a decrease in the utilization of POPs at the studied area. The possible input for the reservoirs is the atmosphere but it is reasonable to believe that urban runoff may be a source of contamination for the Paraíba do Sul system. The potential sources of PAHs for both reservoirs include emissions from large coal burning metallurgical industries, domestic and mixed industrial effluents, street runoff and atmospheric deposition.

This sort of study is useful to evaluate the effectiveness of legislative actions on contaminant input. However, little research has been done on Brazilian watersheds. There is an urgent need for environmental action and control to guarantee the protection of aquatic environments in Brazil, specifically the ones used as a source of drinking water, which is the case of the Paraíba do Sul-Guandu Rivers system.

\section{ACKNOWLEDGEMENTS}

This study was supported by CAPES (Coordenação de Aperfeiçoamento de Pessoal de Nível Superior) and PRONEX/CNPq (Conselho Nacional de Pesquisas). The chromatographic laboratory was built during a Joint Research Project funded by Commission of the European Community (Project number: C11*-CT93-0055). Dr. J. Torres is an Advance Selikof Fellow at the Mount Sinai School of Medicine and Queens College in New York and is supported in part by Grant 1 D43 TW00640 from the Fogarty International Center of the National Institute of Health.

\section{REFERENCES}

1. Netto, A D. P.; Moreira, J. C.; Dias, A. E. X. O.: Arbilla, G.; Ferreira, L. F. V.; Oliveira, A.S.; Bareck, J.; Quim. Nova 2000, 26, 765.

2. Blumer M.; Sci. Am. 1976, 234, 35; Lopes, W. A.; Andrade, J. B.; Quim. Nova 1996, 19, 497.

3. Edwards, N. T.; J. Environ. Qual. 1983, 12, 427.

4. Vasconcellos, P. C.; Artaxo, P. E.; Coccioli, P.; Cecinato, A.; Bracaleoni, E.; Frattoni, M.; Quim. Nova 1998, 21, 385.

5. Cerniglia C. E.; Biodegradation 1992, 3, 351.

6. Gschwend, P. M.; Hites, R. A.; Geochim. Cosmochim. Acta 1981, 45, 2359.

7. Colombo, J. C.; Pelletier, E.; Brochu, C.; Khalil, M.; Catoggio, J. A.; Environ. Sci. Technol. 1989, 23, 888.

8. Vieira, E. D. R.; Torres, J. P. M.; Malm, O.; Environ. Res. Section A 2001, 86, 174; D’Amato, C.; Torres. J. P. M.; Malm, O.; Quim. Nova 2002, 25, 995.

9. Morrison, R. D.; Newell, A. E.; J. Soil Sci. 1999, 8, 63.

10. Kelce, W. R.; Stone, C. R.; Laws, S. C.; Earl, G. L.; Kemppalnen, J. A.; Wilson, E. M.; Nature 1995, 375, 581; Fry, M.; Environ. Health Perspect. 1995, 103 (Suppl. 7), 165; Strömpl, C.; Thiele, J. H.; Arch. Environ. Contam. Toxicol. 1997, 33, 350; Aislabie, J. M.; Richards, N. K.; Buol, H. L.; N. Z. J. Agric. Res. 1997, 40, 269.
11. Lyche, J. L.; Skaare, J. U.; Larsen, H. J. S.; Ropstad, E.; Chemosphere 2004, 55, 621 .

12. Walker, W. J.; McNutt, R. P.; Maslanka, C. A. K.; Chemosphere 1999, 38, 363.

13. Torres, J. P. M.; Pfeiffer, W. C.; Markowitz, S.; Pause, R.; Malm, O.; Japenga, J.; Environ. Res. Section A 2002, 88, 134.

14. Oehme, M.; Sci. Total Environ. 1991, 106, 43.

15. Safe, S. H.; Crit. Rev. Toxicol. 1994, 24, 87.

16. Carpinter, D. O.; Int. J. Occup. Med. Environ. Health 1998, 11, 291.

17. Wasserman, J. C.; Figueiredo, A. N. G.; Pellegatti, F.; Silva-Filho, E. V.; J. Geochem. Explor. 2001, 72, 129.

18. Godoy, J. M.; Padovani, C. R.; Guimarães, J. R. D.; Pereira, J. C. A.; Vieira, L. M.; Carvalho, Z. L.; Galdino, S.; J. Braz. Chem. Soc. 2002, 13, 71.

19. Lima A. L. C.; Master's Dissertation, Pontifica Universidade Católica do Rio de Janeiro, Brazil, 1996.

20. Torres, J. P. M.; Malm, O.; Vieira, E. D. R.; Japenga, J.; Koopmans, G. F.; Ciência e Cultura 1999, 51, 54.

21. Koopmans G.; Master's Dissertation, State University of Groningen, Groningen, 1996.

22. Coelho, V. M.; Fundação Estadual de Engenharia e Meio Ambiente, Brazil, 1990; Coelho, V. M.; Fonseca, M. R.; Proceedings of the Pan American Health Organization, Washington, 1988.

23. Tavares, T. M.; Beretta, M.; Costa, M. C.; Chemosphere 1999, $38,1445$.

24. Souza, N. E.; Rubira, A. F.; Matsushita, M.; Tanamati, A.; Arch. Biol. Technol. 1988, 31, 587.

25. Japenga, J.; Wagenaar, W. J.; Salomons, W.; Sci. Total Environ. 1988, 75, 249.

26. Racke, K. D.; Skidmore, M.; Hamilton, D.; Unsworth, J. B.; Miyamoto, J.; Cohn, S. Z.; Pesticides fate in a Tropical soil: Technical report, IUPAC Report on Pesticides XX, 1997.

27. WHO (World Health Organization); DDT and Its Derivates Environmental Aspects, Environmental Health Criteria 83, Geneva, 1989.

28. Khan, S. U; J. Environ, Sci. Health B 1994, 29, 205; Andrea, M. M.; Luchini, L. C.; Mello, M. H. S. H.; Tomita, R. Y.; Mesquita, T. B.; Musumeci, M. R.; J. Environ. Sci. Health B 1994, 29, 121.

29. Yunker, M. B.; Macdonald, R. W.; Goyette, D.; Paton, D. W.; Fowler, B. R.; Sullivan, D.; Boyd, J.; Sci. Total Environ. 1999, 225, 181.

30. Yunker, M. B.; Macdonald, R. W.; Vingarzan, R.; Mitchell, H.; Goyette, D.; Sylvestre, S.; Org. Geochem. 2002, 33, 489.

31. Budziski, H.; Jones, I.; Bellocq, J.; Piérard, C.; Garrigues, P.; Mar. Chem. 1997, 58, 85 .

32. Soclo, H. H.; Garrigues, P. H.; Ewald, M.; Mar. Pollut. Bull. 2000, 40, 387.

33. Willians, P. T.; Bartle, K. D.; Andrews, G. E.; Fuel 1986, 65, 1150.

34. Wakeham, S. G.; Shaffner, C.; Ginger, W.; Geochim. Cosmochim. Acta 1980, 44, 415; Readman, J. W.; Mantoura, R. F. C.; Llewellyn, C. A.; Preston, M. R.; Reeves, A. D.; Int. J. Environ. Anal. Chem. 1986, 27, 29.

35. Lee, M. L.; Howard, J. B.; Hites, R. A.; Biomed. Mass Spectrom. 1977, 4, 182; Li, C. K.; Kames, R. M.; Atmos. Environ. 1993, 27A, 523.

36. Jenkins, B. M.; Jones, A. D.; Turn, S. Q.; Willians, R. B.; Environ. Sci. Technol. 1996, 30, 2462.

37. Fine, P. M.; Cass, G. R.; Simonei, B. R.; Environ. Sci. Technol. 2001, 35, 2665.

38. Halsall, C. J.; Swetman, A. J.; Barrie, L. A.; Jones, K. C.; Atmos. Environ. 2001, 35, 255.

39. Fetter, C. W.; Contaminant Hydrogeology, Prentice Hall: New Jersey, 1992.

40. Cousins, I. T.; Beck, A. J.; Jones, K. C.; Sci. Total Environ. 1999, $228,5$.

41. Behymer, T. D.; Hites, R. A.; Environ. Sci. Technol. 1988, 22, 1311.

42. Baker, J. E.; Eisenreich, S. J.; Eadie, B. J.; Environ. Sci. Technol. 1991, 25, 500; Tolosa, I.; Bayona, J. M.; Albaigés, J.; Environ. Sci. Technol. 1996, 30, 2495; Simó, R.; Grimalt, J. O.; Albaigés, J.; Environ. Sci. Technol.1997, $31,2697$.

43. Stalikas, C. D.; Chaidou, C. I.; Pilidis, G. A.; Sci. Total Environ. 1997, 204, 135.

44. Yamashita, N.; Kannan, K.; Imagawa, T.; Villeneuve, D. L.; Hashimoto, S.;Miyazaki, A.; Giesy, J. P.; Environ. Sci. Technol. 2000, 34, 3560.

45. Baumard, P.; Budziski, H.; Garrigues, P.; Mar. Pollut. Bull. 1998, 36, 577.

46. Yunker, M. B.; Macdonald, R. W.; Org. Geochem. 2003, 34, 1525.

47. Sincre, M. A.; Marty, J. C.; Saliot, A.; Aparicio, X.; Grimalt, J.; Albaigés, J.; Atmos. Environ. 1987, 21, 2247; Gugou, A.; Stratigakis, N.; Kanakidou, M., Stephanou, E. G.; Org. Geochem. 1996, 25, 79.

48. Masclet, P.; Cachier, H.; Liousse, C.; Wortham, H.; J. Atmos. Chem. 1995, $22,41$.

49. Robbins, J. A.; Edigington, D. N.; Geochim. Cosmochim. Acta 1975, 39, 285.

50. Quevauviller, P.; Donard, O. F. X.; Wasserman, J. C.; Martin, F. M.; Schenider, J.; Appl. Organomet. Chem. 1992, 6, 221. 